\title{
Drinking Water Quality Assessment in Selected Barangays in Laoang, Northern Samar, Philippines
}

\author{
Merle N. Tonog and Marieta M. Poblete
}

\begin{abstract}
This study aimed to assess drinking water quality of the different water sources in Barangays Vigo, Yapas and Tinoblan in Laoang Northern Samar. Water sources were: deep well, pump well and communal faucets. Water quality is based on the physical, chemical and bacteriological properties for each of the eight sampling stations. Three sampling periods were made at an interval of at least 15 days from January-February, 2012. Findings revealed that most water sources were within the permissible limits in terms of color, odor, pH, total dissolved solids (TDS), salinity, dissolved oxygen (DO) and nitrite. However, hardness and alkalinity were beyond the allowable limits. All water samples were positive for fecal coliforms. Thus, this study concludes that all water sources tested are not safe and not potable.
\end{abstract}

Index Terms-Barangays, nitrite, water quality, water sources.

\section{INTRODUCTION}

Contamination of drinking water remains a problem in rural areas where deep well, common faucets and sometimes water direct from streams or springs are the available sources which does not undergo proper water treatment before it is consumed. In 2010 and 2011, results of the morbidity reports for water-borne diseases from Rural Health Unit in Laoang, Northern Samar (LNS) and in hospital was alarming [1]. Acute gastroenteritis, cholera and typhoid fever ranked first [2], [3]. Thus, this study aimed to assess the drinking water quality of the three barangays. Specifically, it tried to determine the physical, chemical and bacteriological properties [4] of these drinking water sources and compared these parameters with the standards set by the Department of Environmental and Natural Resources (DENR) [5].

\section{MATERIALS AND METHODS}

Eight sampling stations were purposively selected from the three barangays. Three sampling periods with three trials for each parameter were taken from January-February 2011. The flow diagram of the study is shown in Fig. 1. Water samples from deep wells were collected using an improvised water sampler. For faucets and jetmatic pumps, water was run and pumped sufficiently before samples were taken. Analysis for physical properties like color and odor were recorded by a panel of evaluators while $\mathrm{pH}$ and TDS were

Manuscript received March 27, 2014; revised May 25, 2014

Merle N. Tonog is with the University of Eastern Philippines, Philippines (e-mail: merletonog@yahoo.com).

Marieta M. Poblete is with Vigo National High School, Laoang, Northern Samar (e-mail: mpoblete@yahoo.com). determined using $\mathrm{pH}$ and TDS meter respectively These tests were done on site.

To determine the chemical properties like salinity, a refractometer was used; nitrite - UV-Vis spectrophotometer [6], DO - azide determination [7]; hardness - magnesium hardness determination; alkalinity - titration method [4]. For bacteriological property, Escherichia coli - membrane filtration technique was used [4]. Results of the analysis were compared with the standards set by DENR [5].

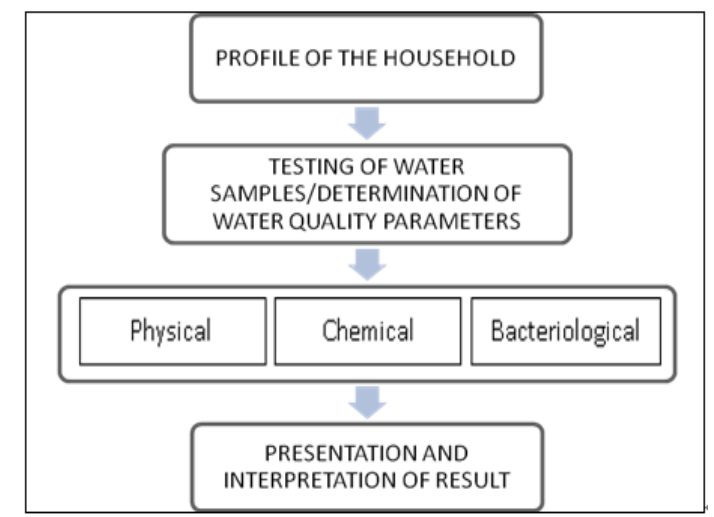

Fig. 1. Flow diagram of the study.

Descriptive method present results using tables, averages and graphs. The data gathered was computed using frequency distribution and averages. Three trials for each parameter were taken from the sampling stations for three consecutive samplings. Averages and means were computed and recorded. Except for nitrite and fecal coliform where it only had one sampling with three trials.

\section{RESULTS AND DISCUSSIONS}

This study discussed on the physical, chemical and bacteriological properties of each of the sampling stations. Results were compared with the standards [3].

\section{A. Physical Properties}

The physical properties taken from the sampling stations were the following: color, odor, $\mathrm{pH}$ and TDS.

Table I showed that color, odor, $\mathrm{pH}$ and TDS of the different sampling sites were within the acceptable limits. Most sampling stations water sources color were clear and odorless.

Fig. 2 shows that $\mathrm{pH}$ reading ranges from 5.9 to 7.7 for the first, second and third sampling periods. Sampling site 7 was consistent to have the lowest average. Site 5 in Yapas and site 8 in Tinoblan which are communal faucets, have the neutral $\mathrm{pH}$ of 7 . This simply means that neither acid nor alkalinity is present in this water source, like distilled water. While in 
Tinoblan site 7, a deep well, has slightly acidic water with a $\mathrm{pH}$ of 6.48. A measurement below 7 means that acid was present. Although, from the final data on the Fig. 2 and Table
I, it can be concluded that all water samples were within the allowable limits for $\mathrm{pH}$ which is 6.5 to 8 in drinking water, except for sampling site 7 which is below $\mathrm{pH} 6.5$.

TABLE I: PHYSICAL PROPERTIES OF THE DRINKING WATER SOURCES OF VIGO, YAPAS AND TINOBLAN

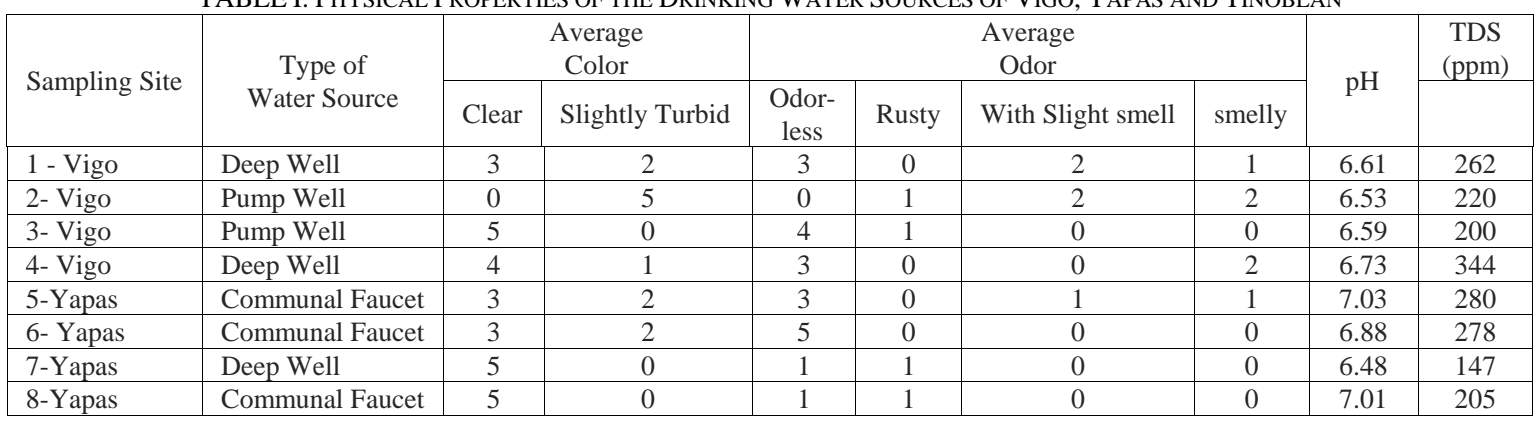

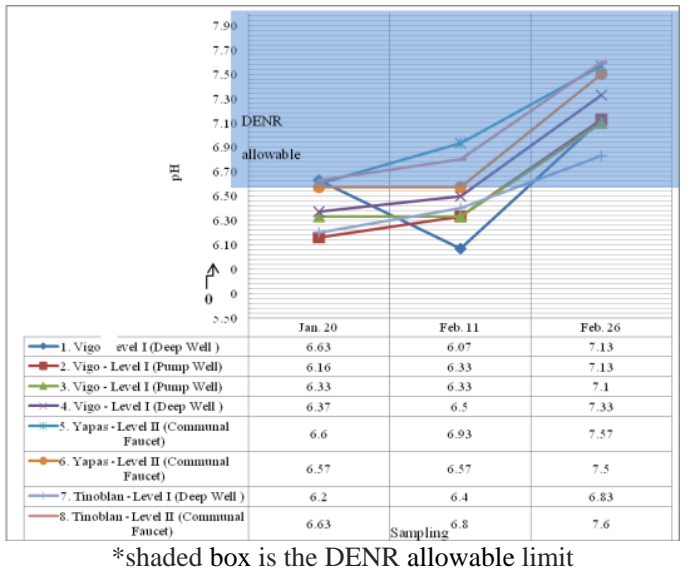

Fig. 2. pH of the different drinking water sources.

It was also observed, that site number 5, 6 and 7 which were Level II, communal faucets had higher $\mathrm{pH}$ compared to those from Level I, deep wells and pump wells. With increasing $\mathrm{pH}$ means water is more alkaline, this is good to human health.

Data for TDS was taken using TDS meter. The result showed varied intervals. During the first sampling it ranges from 60 to $113 \mathrm{mg} / \mathrm{L}$ or parts per million (ppm) with an interval of 73. In the second sampling it ranges from 220 to 520 with an interval of 300 . In the third sampling it ranges from 160 to 305 with and interval of 145 . However, the pattern observed in the line graph is the same for the three samplings may it be sunny, cloudy or rainy day for all types of drinking water sources studied.

The final data shown in the line graph on Fig. 3 reveals that sampling site 4, a deep well, in Vigo, has the highest TDS and site 7 a deep well in Tinoblan, has the lowest TDS. Site 4 probably holds more wastes from sewage or run-offs compared with other water sources. However, it can be concluded that all sampling sites were within the allowable limits for TDS where the maximum acceptable level is $500 \mathrm{mg} / \mathrm{L}$ or ppm in drinking water. Beyond the allowable limits could affect water taste and health risks. This implied that source in site 7 was the farthest from sewage run-offs which adds to the amount of TDS in water. If proper cleaning and maintenance will just be regularly applied in the deep well it could be a better source for drinking.

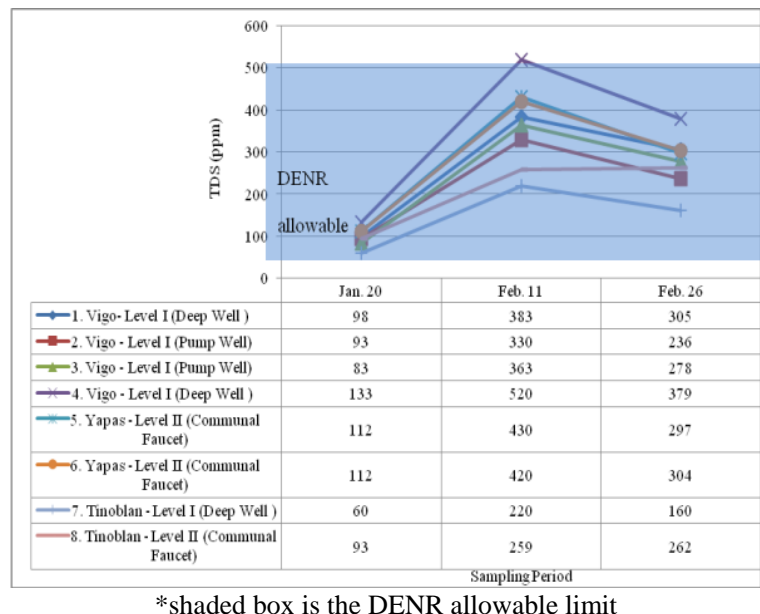

Fig. 3. Total dissolved solids (TDS) of the different drinking water source.

The type of water sources did not show any consistency for TDS. Since there is Level I, deep wells with high and low TDS present, like in communal faucets, Level II type of water source.

Table II presents the average data of chemical properties on the three samplings sites in Vigo, Yapas and Tinoblan. Nitrite and dissolved oxygen were still within the allowable limits for DENR standards for all sampling sites. However, for alkalinity and hardness all sampling sites are beyond the allowable limits.

TABLE II: CHEMICAL PROPERTIES OF THE DRINKING WATER SOURCES OF VIGO, YAPAS AND TINOBLAN
\begin{tabular}{|l|c|c|c|c|c|}
\hline $\begin{array}{c}\text { Sampling } \\
\text { Site }\end{array}$ & $\begin{array}{c}\text { Type of Water } \\
\text { Source }\end{array}$ & $\begin{array}{c}\text { Nitrite } \\
\mathrm{mgN} / \mathrm{L}\end{array}$ & $\begin{array}{c}\text { DO } \\
(\mathrm{ppm}) \mathrm{mg} / \mathrm{L}\end{array}$ & $\begin{array}{c}\text { HARDNESS } \\
\mathrm{ppm} / \mathrm{mg} / \mathrm{L}\end{array}$ & $\begin{array}{c}\text { ALKALINITY } \\
\mathrm{ppm} / \mathrm{mg} / \mathrm{L}\end{array}$ \\
\hline 1- Vigo & Deep Well & 0.239 & 9.9 & 400 & 343 \\
\hline 2- Vigo & Pump Well & 0.007 & 5.02 & 494 & 329 \\
\hline 3- Vigo & Pump Well & 0.001 & 6.49 & 362 & 379 \\
\hline 4- Vigo & Deep Well & 0.001 & 4.82 & 369 & 366 \\
\hline 5- Yapas & Communal Faucet & $<0.001$ & 8.34 & 355 & 446 \\
\hline 6- Yapas & Communal Faucet & 0.001 & 9.84 & 388 & 455 \\
\hline 7- Tinoblan & Deep Well & 0.002 & 6.62 & 289 & 195 \\
\hline 8- Tinoblan & Communal Faucet & $<0.001$ & 9.28 & 394 & 384 \\
\hline
\end{tabular}




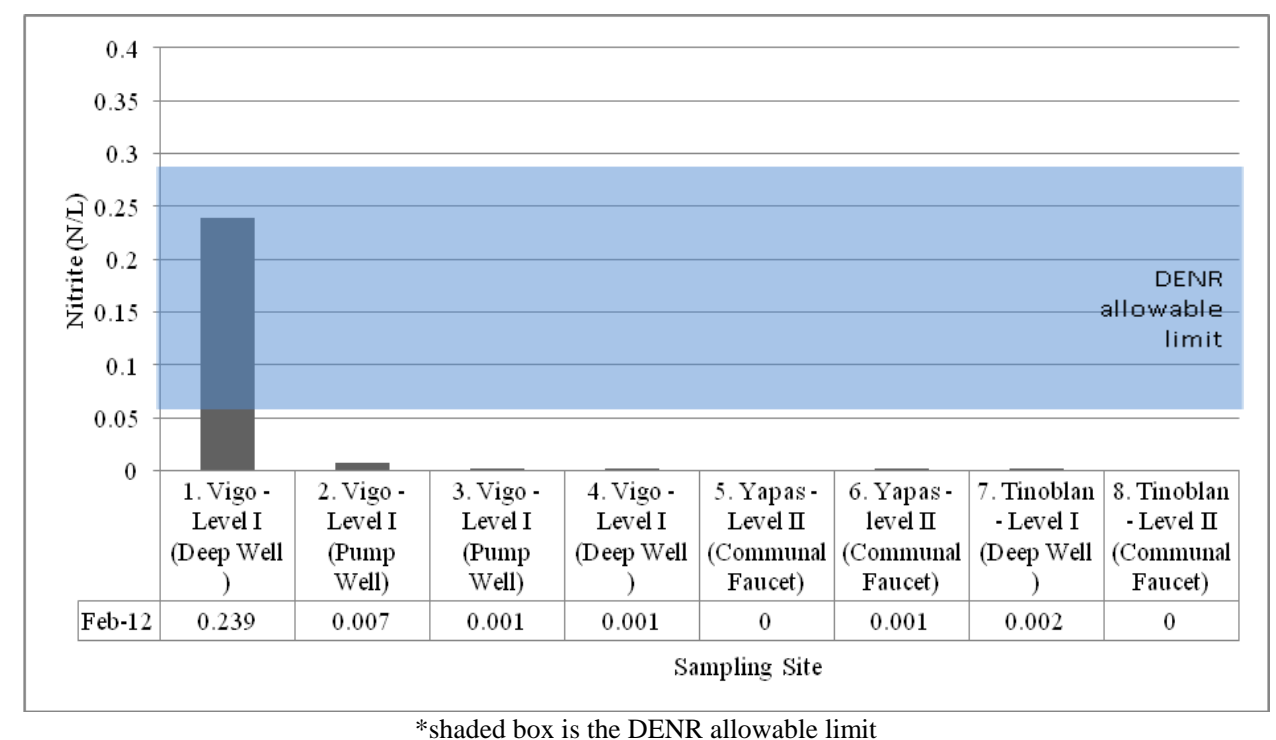

Fig. 4. Nitrite of the different drinking water sources.

A deep well in site 1 in Vigo had the highest presence of Nitrite and sampling sites 5 and 8 have the lowest as shown in Fig. 4. Concrete evidence for sampling site 1 has a high presence of nitrite compared with the rest of the sampling sites was that animal wastes from pigs were near the water source. However, it could still be deduced that the drinking water sources studied in the three barangays were still free from leaking septic tanks since it was still below the permissible limit of $3 \mathrm{mg} / \mathrm{L}$. High presence of nitrite results from leaching or run-offs from agricultural land and contamination from human waste or animal waste.

Among the types of water sources, it was the Level II type, communal faucets, had the lowest presence of Nitrite which means that it is the safest from leaking septic tanks or run-offs since its water pipe is from a protected spring. In this case there were no leaking pipes near contaminated run-offs.

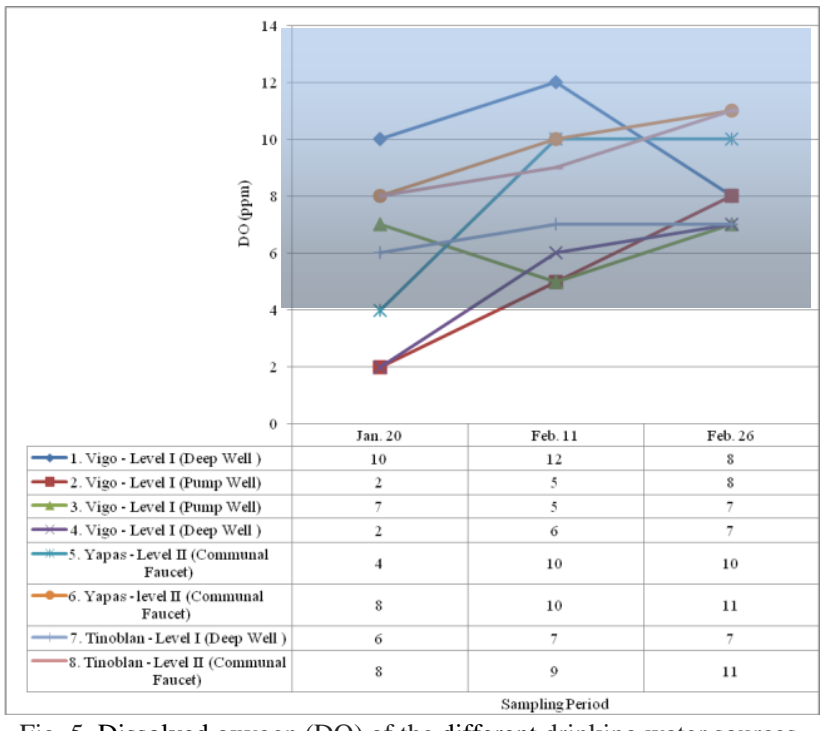

Fig. 5. Dissolved oxygen (DO) of the different drinking water sources.

Fig. 5 shows that three sampling sites, a deep well and 2 communal faucets, have high DO at 9.9 to 9.28 ranges, the rest are below 9 with the lowest of 4.82. A small amount of DO adds to better tasting of drinking water. Sampling site 1, a deep well, in Vigo and site 6, a communal faucet, in Yapas have the highest dissolved oxygen. While sampling site 4 , a deep well in Vigo has the lowest. Low DO in water maybe due to a warm condition and can be an indication of too much bacteria from sewage or organic discharges. Warm water condition increases molecular activity which pushes DO to evaporate and bacteria consume DO causing it to decrease. Since high DO results to the better taste of drinking water site 1, a deep well in Vigo and site number 6, a communal faucet in Yapas, have the best taste among the sites studied.

Among the types of water sources all Level II, communal faucets had high DO although a Level I, a deep well in Vigo, also had a high DO reading.

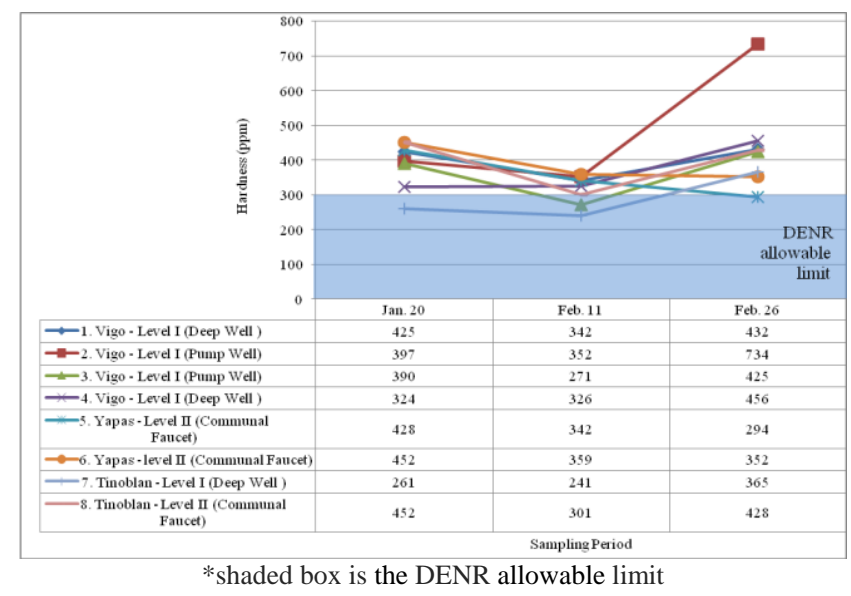

Fig. 6. Hardness of the different drinking water sources.

Fig. 6 revealed that sampling site 2 had the highest water hardness value while sampling site 7 has the lowest. The figure showed that sampling site 2, a pump well in Vigo has the highest hardness of water at an average of $494 \mathrm{ppm}$ or $\mathrm{mg} / \mathrm{L}$ while site 7 has the lowest of $289 \mathrm{ppm}$. It can be concluded that all water samples were "very hard" and were not in the allowable maximum limits of $300 \mathrm{mg} / \mathrm{L}$ for drinking water, except for sampling site 7 . It indicates that most water sources will precipitate in soap. This is an indication of the presence of calcium and magnesium and is expressed as ppm calcium carbonate.

Hardness in water is due to the mineral calcium which is essential to our body. But hard water can cause build up on fixtures, dishes and utensils and poor soap and detergent 
performance. Its alkaline taste makes coffee bitter and lowers the efficiency of electric water heater. Furthermore, all of the water sources studied have high water hardness may it be a Level I or Level II type of water source.

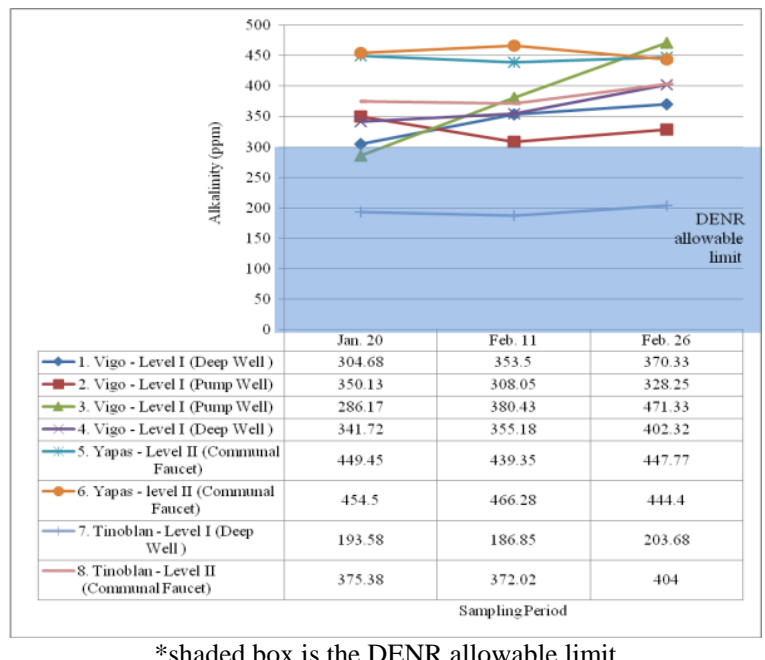

*shaded box is the DENR allowable limit

Fig. 7. Alkalinity of the different drinking water sources.

Fig. 7 revealed that sampling site 6, a communal faucet in Yapas has the highest alkalinity of water and site 7 has the lowest. Main sources for alkalinity are rocks, which contain carbonate, bicarbonate and hydroxide compounds. Only sampling site 7, a deep well was within the permissible limit of $300 \mathrm{mg} / \mathrm{L}$. This result implied that most of the water studied were "very hard" water which indicate the presence of many carbonates and bicarbonates.

Alkalinity of water is its capacity to neutralize acid which is independent of the sample. This means that whatever is the amount of the sample, its power to react with acid and buffer its $\mathrm{pH}$ will still be the same. So that the higher the alkalinity the better its buffering capacity. This makes water become less vulnerable to acid rain.

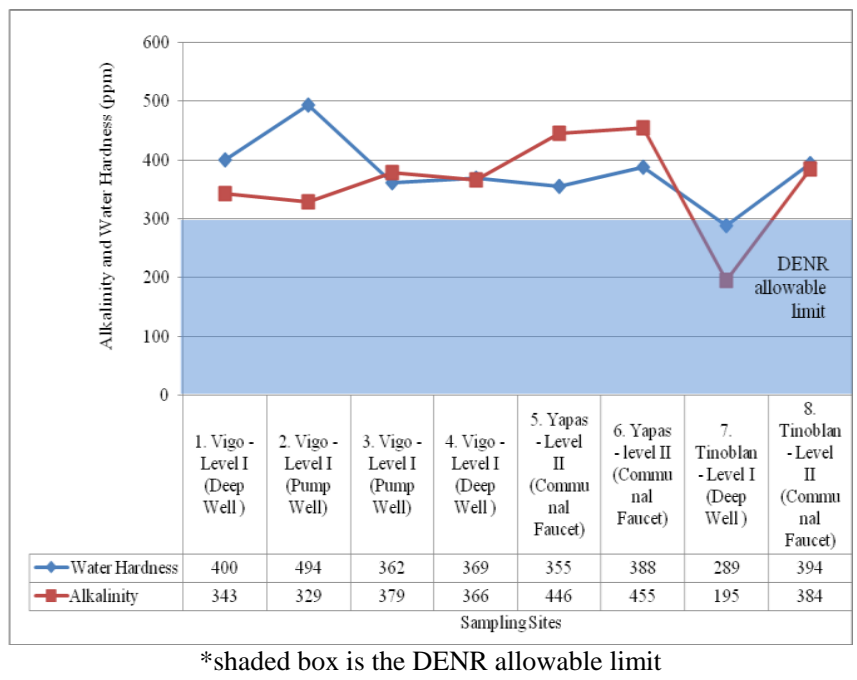

Fig. 8. Alkalinity and hardness of the different drinking water sources.

Table II shows the comparison of the average data between water hardness and alkalinity. It can be observed that the data for the two parameters are closely related where most sampling sites have high result except for sampling site number 7. Sampling site number 2 has the greatest difference in hardness and alkalinity.
As observed in Fig. 8, station 2 had a highest hardness value, while station 7 lowest. Similar trend occurs as to the Alkalinity. Fig. 8 indicates that these drinking water sources have very hard water. It implies the presence of carbonates of magnesium and calcium. Though these values affect some pipes and lather capacity during laundry these calcium and magnesium are minerals that add to the sweet taste of water.

\section{B. Bacteriological Properties}

Table III gives the result on the fecal coliform determination for the sampling sites studied in barangay Vigo, Yapas and Tinoblan.

The data on Table III shows that all sampling sites; Level I, deep well and pump well and Level II, communal faucets, indicate that these are positive for fecal contamination. This means that water samples are contaminated with Escherichia coli and water are not safe for drinking.

This also mean that water sources in these barangays are not safe because there are bacteria that can cause diarrhea, gastroenteritis, typhoid fever and other water borne related diseases.

TABLE III: FECAL COLIFORM OF THE DRINKING WATER SOURCES OF VIGO, YAPAS AND TINOBLAN

\begin{tabular}{|c|c|c|l|}
\hline $\begin{array}{c}\text { Sampling } \\
\text { Site }\end{array}$ & $\begin{array}{c}\text { Type of Water } \\
\text { Source }\end{array}$ & $\begin{array}{c}\text { Fecal } \\
\text { Coliform }\end{array}$ & \multicolumn{1}{|c|}{ Interpretation } \\
\hline 1 & Deep Well & + & $\begin{array}{l}\text { Positive for fecal } \\
\text { coliform }\end{array}$ \\
\hline 2 & Pump Well & + & $\begin{array}{l}\text { Positive for fecal } \\
\text { coliform }\end{array}$ \\
\hline 3 & Pump Well & + & $\begin{array}{l}\text { Positive for fecal } \\
\text { coliform }\end{array}$ \\
\hline 4 & Deep Well & + & $\begin{array}{l}\text { Positive for fecal } \\
\text { coliform }\end{array}$ \\
\hline 5 & Communal Faucet & + & $\begin{array}{l}\text { Positive for fecal } \\
\text { coliform }\end{array}$ \\
\hline 6 & Communal Faucet & + & $\begin{array}{l}\text { Positive for fecal } \\
\text { coliform }\end{array}$ \\
\hline 7 & Deep Well & + & $\begin{array}{l}\text { Positive for fecal } \\
\text { coliform }\end{array}$ \\
\hline 8 & Communal Faucet & + & $\begin{array}{l}\text { Positive for fecal } \\
\text { coliform }\end{array}$ \\
\hline
\end{tabular}

\section{Research Data and DENR Standards}

Table IV gives the research data and the DENR standards [3] applied for the parameters studied on the drinking water sources in Vigo, Yapas and Tinoblan, Laoang.

TABLE IV: TABLE OF THE AVERAGE RESEARCH DATA AND DENR

\begin{tabular}{|c|c|c|c|}
\hline \multicolumn{4}{|c|}{ STANDARD } \\
\hline \multicolumn{2}{|c|}{ PARAMETERS } & Research Data & DENR Standard \\
\hline \multirow{4}{*}{$\begin{array}{l}\text { Physical } \\
\text { Property }\end{array}$} & Color & Clear & Unobjectionable \\
\hline & Odor & Odorless & Unobjectionable \\
\hline & $\mathrm{pH}$ & $6.48-7.03$ & 6.5 to 8.0 \\
\hline & $\begin{array}{l}\text { Total } \\
\text { Dissolved } \\
\text { Solids } \\
\end{array}$ & $\begin{array}{c}147-344 \\
\mathrm{mg} / \mathrm{L}\end{array}$ & $500 \mathrm{mg} / \mathrm{L}$ \\
\hline \multirow{5}{*}{$\begin{array}{l}\text { Chemical } \\
\text { Property }\end{array}$} & Salinity & 0.00 & 0 \\
\hline & Nitrite & $\begin{array}{c}<0.001-0.239 \\
\mathrm{mgN} / \mathrm{L}\end{array}$ & $3 \mathrm{mg} / \mathrm{L}$ \\
\hline & $\begin{array}{l}\text { Dissolved } \\
\text { Oxygen }\end{array}$ & $\begin{array}{c}4.82-9.9 \\
\mathrm{mg} / \mathrm{L}\end{array}$ & $\begin{array}{c}\min .=5, \text { thehigher } \\
\text { the better }\end{array}$ \\
\hline & Hardness & $\begin{array}{c}289-494 \\
\mathrm{mg} / \mathrm{L}\end{array}$ & $300 \mathrm{mg} / \mathrm{L}$ \\
\hline & Alkalinity & $\begin{array}{c}195-455 \\
\mathrm{mg} / \mathrm{L}\end{array}$ & $300 \mathrm{mg} / \mathrm{L}$ \\
\hline $\begin{array}{l}\text { Bacteriological } \\
\text { Property }\end{array}$ & $\begin{array}{l}\text { Fecal } \\
\text { Coliform }\end{array}$ & positive & $0 / 100 \mathrm{~mL}$ \\
\hline
\end{tabular}


As shown on Table IV all average data for physical properties; color, odor, $\mathrm{pH}$ and TDS are within the range for acceptable limits set by DENR. While for chemical properties only salinity, nitrite and dissolve oxygen are within the allowable limits and hardness and alkalinity are beyond the permissible limit.

\section{CONCLUSION}

Based on the result of the study the following conclusions are drawn:

1) For physical properties, most of the sampling sites have unobjectionable color and odor. For water $\mathrm{pH}$, only 2 sites had neutral $\mathrm{pH}$ the rest contains acid especially sampling 7 which is below the permissible limit. For total dissolved solids all sampling sites are within the acceptable limit.

2) Chemical properties in all sampling sites have zero salinity, nitrite and dissolved oxygen are still in the permissible limits while hardness and alkalinity are beyond the allowable limit. Hardness and alkalinity implied that these water sources would precipitate and form scum. This can lead to clogging of pipes and drains.

3) For bacteriological property all sampling sites are positive for fecal coliforms. This implied that all water sources are not safe for drinking. This result confirmed that the cause of most death in these three barangays was due to unsafe drinking water.

4) In terms of the type of water source, Level II or communal faucet had better water quality parameters in terms of $\mathrm{pH}$, total dissolve solids, nitrite and dissolved oxygen.

\section{RECOMMENDATIONS}

Based on the results and observations on the study, the following are hereby recommended:

1) Since the deep wells, pump well and communal faucets are representative of the water sources where the barangay consumers get water for drinking, they need to know the status of their drinking water source. They should know that they need to treat or purify the water before it is used for drinking or for cooking.

2) Since all of the water sources are not safe for drinking the government through the barangay health center in coordination with the barangay council, the department of health and sanitary inspector in the local government units should go hand in hand to conduct seminars on water purification and treatment and provide the consuming public with the necessary requirements in the process.

3) The consuming public should be helped in the practice of proper sanitation, preservation and care of their water in safeguarding themselves for future diseases or possible gastroenteritis where growing children and school age are susceptible.

4) The academe should help disseminate the information to their students and share what they learned about the possible effect of drinking unsafe or untreated water and its effects not just in getting water borne diseases but also its effect to student's scholastic achievement.

5) In doing water quality testing:

- In pump wells water samples should be taken after letting the several liters of water run or flow thoroughly.

- For nitrite determination, water sample should be allowed to stand overnight or pump out water several times from the source to reduce nitrite, $\mathrm{NO}^{-}$and should be analyzed within an hour after getting the sample.

6) Based on the result of the study, Level II type of water source had better water quality parameters than Level I, so it is recommended.

7) Further test on the types of fecal coliform is recommended.

\section{REFERENCES}

[1] Morbidity Report on Field Health Service Information System (FHSIS) for 2010 and 2011 in Laoang, Northern Samar, Rural Health Unit, Laoang, Northern Samar, Philippines, 2012.

[2] G. B. Tan, Hospital Annual Statistical Report, 2010 and 2011.

[3] Environmental Health Services, "Actual Count of Families with or Without Water Sealed Toilet \& Source of Water Supply in Barangay Vigo, Yapas and Tinoblan," Provincial Sanitary Inspector, RHU, Laoang, Northern Samar.

[4] J. Bartram and R. Balance, "Water Quality Monitoring: A practical guide to the design and implementation of freshwater quality studies and monitoring programmes," WHO, 1996.

[5] Philippine Standards for Drinking Water 1993, DENR Administrative Order No. 26-A, Series, 1994.

[6] Standard Methods for the Examination of Water and Wastewater, $21^{\mathrm{st}}$ Ed., APHA, 2005.

[7] R. Umaly and M. L. Cuvin, Liminology: Laboratory and Field Guide Physico-Chemical Factors Biological Factors, Manila: National Book Store, Inc.

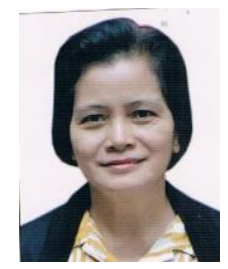

Merle N. Tonog was born in Laoang, Northern Samar on September 26, 1954. She is a graduate with $\mathrm{PhD}$ degree in research and evaluation at the University of San Carlos, Cebu City in October 2009 and a master degree of science in chemistry at the University of the Philippines, October 1991.

She has been teaching several chemistry subjects and research at the University of Eastern Philippines (UEP), Catarman, Northern Samar for more than 30 years. She is a licensed chemical engineer and teacher. She has published a research titled, "Antigenotoxicity of the Structural Derivatives of L-Cysteine to Dimethylnitrosamine, Dimethylhydrazine and Chloroform in albino Mice" Nov.1995 at Pacific Journal of Science and Technology, Vol 8 pp 1-14. She has published a book titled, "A Work/Text in General Chemistry- with teaching and learning styles applications" published by UEP, June 2008. Her research interests are on mutagenicity, health, and environment.

She is a doctor of philosophy in education. She is a member of the Philippine Institute of Chemical Engineers and Integrated Chemists of the Philippines. She was awarded the best completed research for information dissemination by UEP last June 7, 2012 and a plaque of teaching excellence SY 2009-2010. 